\title{
«КРУГЛЫЙ СТОЛ» \\ «ВОСПИТАНИЕ ПОДРАСТАЮЩЕГО ПОКОЛЕНИЯ НА ПРИМЕРЕ УЧАСТНИКОВ ЛОКАЛЬНЫХ ВОЙН И ВОЕННЫХ КОНФЛИКТОВ: ОТ СТРАТЕГИИ К ДЕЙСТВИЮ»
}

\author{
Вал. А. Луков \\ (Московский гуманитарный университет)
}

Аннотация: В статье представлен обзор работы круглого стола под названием «Воспитание подрастающего поколения на примере участников локальных войн и военных конфликтов: от стратегии к действию», который прошел 16 декабря 2015 г. в Московском гуманитарном университете.

Ключевые слова: Московский гуманитарный университет; обзор; круглый стол; воспитание; война

\section{PARTICIPANTS OF LOCAL WARS AND MILITARY CONFLICTS AND THE EDUCATION OF THE NEW GENERATIONS: FROM STRATEGY TO ACTION. A ROUNDTABLE DISCUSSION}

\author{
Val. A. Lukov \\ (Moscow University for the Humanities)
}

\begin{abstract}
This is an overview of the roundtable discussion "Participants of local wars and military conflicts and the education of the new generations: from strategy to action", which took place at Moscow University for the Humanities on December 16, 2015.
\end{abstract}

Keywords: Moscow University for the Humanities; overview; roundtable discussion; education; war

16 декабря 2015 г. в Московском гуманитарном университете состоялся «круглый стол» «Воспитание подрастающего поколения на примере участников локальных войн и военных конфликтов: от стратегии к действию», организованный Советом депутатов муниципального округа «Вешняки», Управой района «Вешняки» и Московским гуманитарным университетом при поддержке государственных органов, органов местного самоуправления, образовательных организаций, общественных организаций Восточного административного округа города Москвы. Проведению «круглого стола» предшествовала большая работа по выработке подходов к организации программ воспитания детей и молодежи и другой 
деятельности в этой области на территории района «Вешняки», в Восточном административном округе с учетом принятия Правительством РФ в мае 2015 г. «Стратегии развития воспитания в Российской Федерации на период до 2025 года», а также других решений, последнего периода, закрепляющих приоритет воспитания подрастающих поколений в деятельности органов государственной власти. Необходимы встречные действия и инициативы по реализации этого стратегического приоритета, идущие от местной власти, от гражданского общества. Эти вопросы неоднократно обсуждались на встречах главы Управы района «Вешняки» П. А. Биды, руководителя аппарата Совета депутатов муниципального округа «Вешняки» А. В. Офицерова и ректора Московского гуманитарного университета профессора И. М. Ильинского, совещаниях рабочей группы, в которую вошли проректор МосГУ Е. А. Белый, директор ИФПИ МосГУ профессор В. А. Луков, председатель РОО «Московский союз орга-низации участников войн и боевых операций» Д. И. Попов и др.

В своем вступительном слове на заседании «круглого стола» ректор Московского гуманитарного университета профессор И. М. Ильинский подчеркнул значение начатой работы по формированию системы совместной деятельности муниципальных образований Восточного административного округа города Москвы, граждан, общественных объединений, направленной на воспитание подрастающего поколения, содействие формированию личности на основе присущей российскому обществу системы ценностей. Он ин-формировал участников «круглого стола» о той работе, которую с начала 1990-х годов проводил Университет, отстаивая приоритет воспитания в деятельности образовательных организаций всех уровней.

О задачах работы по воспитанию детей и молодежи в масштабах района, использовании для этого всех имеющихся ресурсов говорил в своем выступлении глава Управы района «Вешняки» П. А. Бида.

Накопленный опыт работы по воспитанию подрастающего поколения на примере участников локальных войн и военных конфликтов представили на заседании «круглого стола» и. о. председателя Совета ветеранов войны в Египте Ю. Ф. Мякишев, заместитель председателя Правления Московского городского отделения ветеранов войны во Вьетнаме В. Л. Булгаков, генерал-майор афганской армии Мансур Мохаммад Аюбхан Шарифхан, военный наблюдатель ООН А. И. Исаенко, председатель Союза ветеранов Военного института иностранных языков Е. Л. Логинов, директор музея афганской войны в Перово И. Г. Ерин.

Ветеран войны в Афганистане, настоятель Крестовоздвиженского храма в селе Дарна Истринского района, протоиерей отец Константин (К.Г. Волков) особое внимание уделил вопросам формирования духовно- 
го единства молодежи.

Заместитель председателя Московского Союза организаций участников войн и боевых операций по работесучащейся молодежьюД.Ю.Пахомов, рассказал о воспитательном воздействии проекта «От солдата до генерала. Воспоминания о войне», координатором добровольцев по реализации которого он является. Его выступление дополнила участница проекта студентка Е. Сырбул. Об опыте работы по патриотическому воспитанию студентов Московского гуманитарного университета рассказали председатель Студенческого совета МосГУ Д. А. Зеленова и доцент кафедры истории О. Г. Жукова. Они особое внимание обратили на то, как строится работа по включению студентов в изучение местного материала по истории нашей страны, как решается трудная задача превращения молодого человека из объекта воспитательной работы вуза в субъекта этой работы.

Военком Перовского ОВК Е. Г. Машуков обратил внимание на то, что основная работа по патриотическому воспитанию молодежи должна проводиться в общеобразовательной школе, и здесь особую роль играет то, как преподается история России, каково содержание учебников.

После активного обсуждения участники «круглого стола» приняли резолюцию. В ней, в частности, предложено сформировать краткосрочные и среднесрочные комплексные планы работы по воспитанию детей и молодежи в масштабах района, округа. Такие планы должны отразить основные мероприятия, проводимые в сфере воспитания различными участниками воспитательного процесса начиная от дошкольных образовательных организаций, школ, вузов, системы дополнительного образования и до различных бизнес-организаций, общественных объединений, религиозных организаций, общественных инициатив. Для этого предварительно необходимо выявить наличные ресурсы воспитательной работы на данной территории и сформировать социальные карты ресурсного обеспечения этой работы. Предложено также для систематизации работы по воспитанию детей и молодежи в районе, округе создать объединенный штаб, включающий представителей органов государственной власти, органов местного самоуправления, ветеранских, молодежных и детских, иных общественных объединений, религиозных организаций, деловых организаций, расположенных на территории района, округа. В Резолюции подчеркивается, что особым направлением работы по патриотическому воспитанию детей и молодежи на территории района, округа должно стать воспитание подрастающего поколения на примере участников локальных войн и военных конфликтов. Среди многих конкретных действий, намеченных в Резолюции, есть и создание на базе Московского гуманитарного университета историко-патриотического клуба школьников района «Вешняки». 
Итоги «круглого стола», проходившего более трех часов, подвел ректор МосГУ И. М. Ильинский, выразивший удовлетворение результатами обсуждения и призвавший продолжить начатую районными властями и Московским гуманитарным университетом совместную работу по воспитанию подрастающего поколения, добиваясь реального движения от стратегии к действию.

Луков Валерий Андреевич - доктор философских наук, профессор, директор Института фундаментальных и прикладных исследований Московского гуманитарного университета, заслуженный деятель науки Российской Федерации, вице-президент Международной академии наук (IAS, Инсбрук, Австрия), академик Международной академии наук педагогического образования. Адрес: 111395, Россия, г. Москва, ул. Юности, д. 5. Тел.: +7 (499) 374-75-95. Эл. адрес: v-lukov@list.ru

Lukov Valery Andreevich, Doctor of Philosophy, Professor, Director, Institute of Fundamental and Applied Studies, Moscow University for the Humanities; Honored Scientist of the Russian Federation; Vice President, International Academy of Science (Innsbruck, Austria); Full member, International Teacher's Training Academy of Science. Postal address: 5 Yunosti St., 111395 Moscow, Russian Federation. Tel.: +7 (499) 374-75-95. E-mail: v-lukov@list.ru 